\title{
First Haramiyid (Mammalia, Allotheria) from the Mesozoic of Gondwana
}

\author{
Wolf-Dieter Heinrich ${ }^{1}$
}

With 5 figures

\begin{abstract}
A haramiyid tooth is described from the Upper Jurassic of Tendaguru in southwestern Tanzania, East Africa. The specimen, identified tentatively as a lower posterior premolar, is made the holotype of a new taxon, Staffia aenigmatica gen. et sp. nov. which is placed in the Haramiyida. Staffia gen. nov. shares several features with Thomasia from the Late Triassic to Early Jurassic of Europe, notably the arrangement of cusps in two parallel longitudinal rows bordering a central basin, cusp height which progressively decreases in both rows posteriorly, the different height of the rows, the U-shaped posterior rim, and the smooth enamel surface. The main difference between these taxa is the presence of well-developed synclines with rounded floors in Staffia gen. nov., especially that of the principal syncline $\mathrm{LS}_{1}$. Resemblances in the basic tooth crown pattern indicate that occlusion and chewing might have been similar in both genera, but the synclines in Staffia gen. nov. suggest some subtle differences in food processing. Staffia aenigmatica gen. et sp. nov. is the first record of a haramiyid from Gondwana, and also the youngest stratigraphic occurrence for this allotherian group so far.
\end{abstract}

Key words: Mammalia, Allotheria, Haramiyida, Upper Jurassic, Tendaguru, Tanzania, East Africa.

\section{Zusammenfassung}

Ein unterer Backenzahn aus den oberjurassischen Tendaguru-Schichten von Tansania in Ostafrika wird als Staffia aenigmatica gen. et sp. nov. beschrieben und zu den Haramiyida gestellt. Bei dem Fund handelt es sich wahrscheinlich um einen hinteren unteren Prämolaren. Staffia gen. nov. weist zahlreiche Merkmale auf, die bei der spät-triassischen bis früh-jurassischen Gattung Thomasia auftreten. Dazu zählen z. B. die Anordnung der Höcker in zwei unterschiedlich hohen Längsreihen, die in beiden Reihen von vorn nach hinten abnehmende Höckerhöhe, der U-förmige Hinterrand und die glatte Schmelzoberfläche. Die Synklinalen zwischen den Zahnhöckern von Staffia gen. nov. stellen ein neuerworbenes Merkmal dar. Die weitgehenden Übereinstimmungen im Grundaufbau der Zahnkronen beider Gattungen lassen darauf schließen, daß die Kieferbewegung und der Kauvorgang ähnlich waren, doch deuten die Synclinalen bei Staffia gen. nov. auf eine differenziertere Aufbereitung der Nahrung hin. Staffia aenigmatica gen. et sp. nov. ist der erste Nachweis eines Haramiyiden auf dem Gondwana-Kontinent und zugleich der bisher erdgeschichtlich jüngste Beleg für diese Säugetiergruppe.

Schlüsselwörter: Mammalia, Allotheria, Haramiyida, Oberjura, Tendaguru, Tansania, Ostafrika.

\section{Introduction}

For nearly a century, a fragmentary eupantotherian dentary, without teeth, from the Tendaguru Beds in Tanzania was the only known mammalian record from the Upper Jurassic of Africa. The imperfect dentary was briefly described and illustrated by Branca (1916), and later fully described and named as Brancatherulum tendagurense by Dietrich (1927). During the next 70 years no further mammal remains were obtained either from the Tendaguru Beds in Tanzania or from Upper Jurassic deposits elswhere in Africa. In 1995, the author started intensive microvertebrate sampling in dinosaur-bearing matrix from the Tendaguru Beds collected by the German Tendaguru expedition (1909-1913). This program resulted in the discovery of the triconodont Tendagurodon janenschi and the 'eupantothere' Tendagurutherium dietrichi (Heinrich 1998). Microvertebrate sampling of matrix from the Tendaguru dinosaur Beds has continued for the last four years and has now yielded the first haramiyid from the Mesozoic of Gondwana.

Haramiyids are primarily represented by isolated teeth from Upper Triassic to Lower Jurassic (Rhaetic, Rhaeto-Liassic) deposits from Central and Western Europe (e.g., Plieninger 1847, Branca 1915, Simpson 1928a, Parrington 1947, Peyer 1956, Hahn 1973, Clemens 1980, Hahn \&

\footnotetext{
${ }^{1}$ Museum für Naturkunde, Institut für Paläontologie, Invalidenstr. 43, D-10115 Berlin, Germany. Received January 1999, accepted May 1999
} 
Hahn 1983, Sigogneau-Russel 1989, SigogneauRussell \& Hahn 1994; Butler \& McIntyre 1994). Except for taxa of indeterminate affinities (e.g., Hypsiprymnopsis rhaeticus Dawkins 1864, a presumed tritylodont: Hahn \& Hahn 1983) and synonyms (see Butler \& McIntyre 1994), two genera have been distinguished: Thomasia and 'Haramiyia' (e.g., Simpson 1928a, Parrington 1947, Hahn \& Hahn 1983, Kermack et al. 1998). However, the recent discovery of Haramiyavia clemmenseni in the Upper Triassic of Greenland (Jenkins et al. 1997) confirmed suggestions by Sigogneau-Russell (1989) and Butler \& McIntyre (1994) that these genera are based on lower (Thomasia) and upper teeth (Haramiyia) of a single haramiyid genus, for which the senior name is Thomasia (McKenna \& Bell 1997, Kermack et al. 1998).

Thomasia hahni (= Thomasia sp. 1, Hahn 1973: 7, fig. 2; Butler \& McIntyre 1994: 450) from the Upper Norian (Keuper) of Halberstadt in Central Germany and Haramiyavia clemmenseni from the ? Norian-Rhaetic (Tait Bjerg Beds, Østed Dal Member, Fleming Fjord Formation) of East Greenland (Jenkins et al. 1997) are the first haramiyids to appear in the fossil record. Important collections are from the Rhaeto-Liassic of Saint-Nicolas-de-Port (Lorraine) in France (Sigogneau-Russell 1989), Holwell (Somerset) in England (e.g., Parrington 1947, Butler \& McIntyre 1994), Hallau in Switzerland (Peyer 1956, Clemens 1980; Butler \& McIntyre 1994), and Degerloch and Olgahain (Baden-Württemberg) in Germany (e.g., Plieninger 1847, Hahn 1973, Sigogneau \& Hahn 1994). Moreover, a haramiyid molariform tooth has been reported from the Lower Jurassic Kayenta Formation in Arizona (Jenkins et al. 1983, Clemens 1988). By contrast, the affinities of a presumed haramiyid or multituberculate tooth from the Middle Jurassic of England (Freeman 1976) remain obscure.

Allotherian mammals, constituting a subclass of the Mammalia (e.g., Clemens \& Kielan-Jaworowska 1979, Hahn \& Hahn 1983, SigogneauRussell 1989, Kermack et al. 1998), include haramiyids, theroteinids, multituberculates and eleutherodontids (e.g., Hahn et al. 1989, Kermack et al. 1998). Except for multituberculates, most of these primitive mammals are still poorly known due to the incompletenes of the fossil record and, therefore, the interrelationships and classification of the allotherian mammals are still the subject of much dispute (e.g., Hahn \& Hahn 1983, Hahn et al. 1989, Miao 1991, Kielan-Jawo- rowska 1992, Kielan-Jaworowska \& Ensom 1992, Simmons 1993, Butler \& McIntyre 1994, McKenna \& Bell 1997). It should also be noted that cladistic classifications. (McKenna \& Bell 1997) removed haramiyids and theroteinids from the Mammalia sensu stricto to the nonmammalian Mammaliaformes.

\section{Geological and paleontological setting}

The Tendaguru Beds, known primarily for mass accumulations of dinosaur bones, are exposed in southwestern Tanzania. Figure 1 shows the principal subdivision of the Tendaguru Beds in the type area of Tendaguru Hill, following Hennig (1914) and Janensch (1914a, c). The succession of sediments reaches $140 \mathrm{~m}$ thick, and includes three limnic to brackish dinosaur-bearing deposits, the Lower, Middle, and Upper Saurian Beds, and three marine sandstone units, the Nerinea Bed, the Trigonia smeei Bed, and the Trigonia schwarzi Bed (Fig. 1). The haramiyid mammal described here comes from the Middle Saurian Bed.

The highest marine unit of the Tendaguru Beds, the Trigonia schwarzi Bed, has been equated with the lower Lower Cretaceous, and the remaining part of the sequence with the Upper Jurassic (e.g., Hennig 1914, Janensch 1914c, Dietrich 1933, Spath 1927-1933, Aitken 1956, 1961). The Middle and Upper Saurian Beds that yielded the mammalian remains known so far from the Tendaguru Beds are considered to be Kimmeridgian to Tithonian in age (e.g., Aitken 1961, Russell et al. 1980, Schrank, 1999), but the precise age determination requires further biostratigraphic investigations.

Although the Tendaguru Beds cover large areas in southwestern Tanzania (Hennig 1914, Janensch $1914 \mathrm{a}, \mathrm{c}$ ) and many dinosaur localities were discovered in the surroundings of Tendaguru Hill between 1909 and 1913 by the German Tendaguru expedition (Janensch 1914a, 1925a, 1929) and between 1924 and 1931 by the British Tendaguru expedition (Parkinson 1930, Maier 1997), only two mammal-bearing sites have been discovered so far (Fig. 1). Tendaguru Site IV, the type locality of Brancatherulum tendagurense, lies in the Upper Saurian Bed and is located about $800 \mathrm{~m}$ south of Tendaguru Hill (Janensch 1914a: 45), close to Tendaguru site B (Fraas 1908, Janensch 1914a), the type locality of the sauropod Janenschia robusta (Fig. 1). Tendagurodon janenschi, Tendagurutherium dietrichi, and 


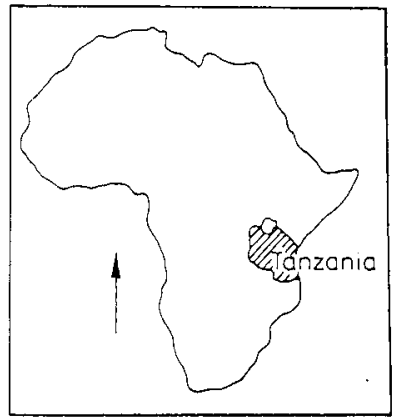

\section{Geographic location and geological structure of Tendaguru, Tanzania}
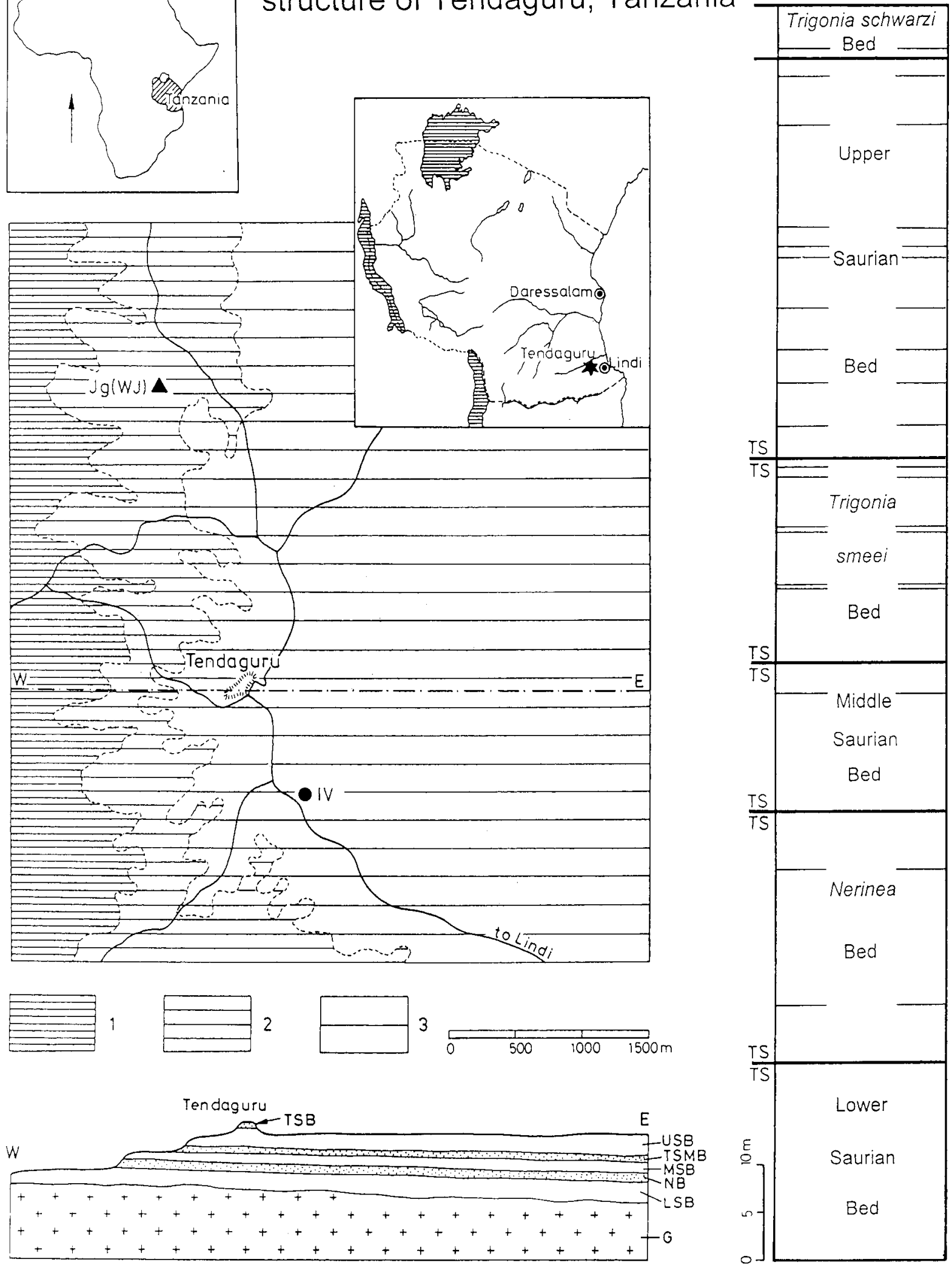

Fig. 1. Map of the Tendaguru area with geological sections and the location of the mammal-bearing sites. Data from Hennig (1914) and Janensch (1914c, 1925a). Note that the marine Nerinea Bed, the two Trigonia Beds, and the Transitional Sands are not mapped in the original site plan (Janensch 1925a: 18), and the Transitional Sands were not distinguished as separate stratigraphical units by Janensch (1914c). 1, Lower Saurian Bed; 2, Middle Saurian Bed; 3, Upper Saurian Bed; TSB, Trigonia schwarzi Bed; USB, Upper Saurian Bed; TSMB, Trigonia smeei Bed; MSB, Middle Saurian Bed; NB, Nerinea Bed; LSB, Lower Saurian Bed; G, gneiss; TS, Transitional Sands; IV, type locality of Brancatherulum tendagurense; Jg (Wj), type locality of Tendagurodon janenschi, Tendagurutherium dietrichi, and Staffia aenigmatica gen. et sp. nov. $\Delta$ - Site in the Middle Saurian Bed, - Site in the Upper Saurian Bed 
the haramiyid mammal described here were obtained from matrix recovered from the Middle Saurian Bed at Site $\mathrm{Jg}(\mathrm{Wj})$, which is situated approximately $2,3 \mathrm{~km}$ north-north-west of Tendaguru Hill (Fig. 1). Tendaguru Site Jg was intensively quarried between 1910 and 1911 by W. Janensch, E. Hennig, and $\mathrm{H}$. von Staff, followed by H. Reck in 1912 who named the locality Wj (Janensch 1914 a). The precise position within the Middle Saurian Bed of the matrix that yielded the haramiyid tooth is unknown due to the lack of excavation data. Therefore, it is still unclear whether the mammalian remains recorded so far are either confined to single layers or irregularly dispersed in the Middle Saurian Bed.
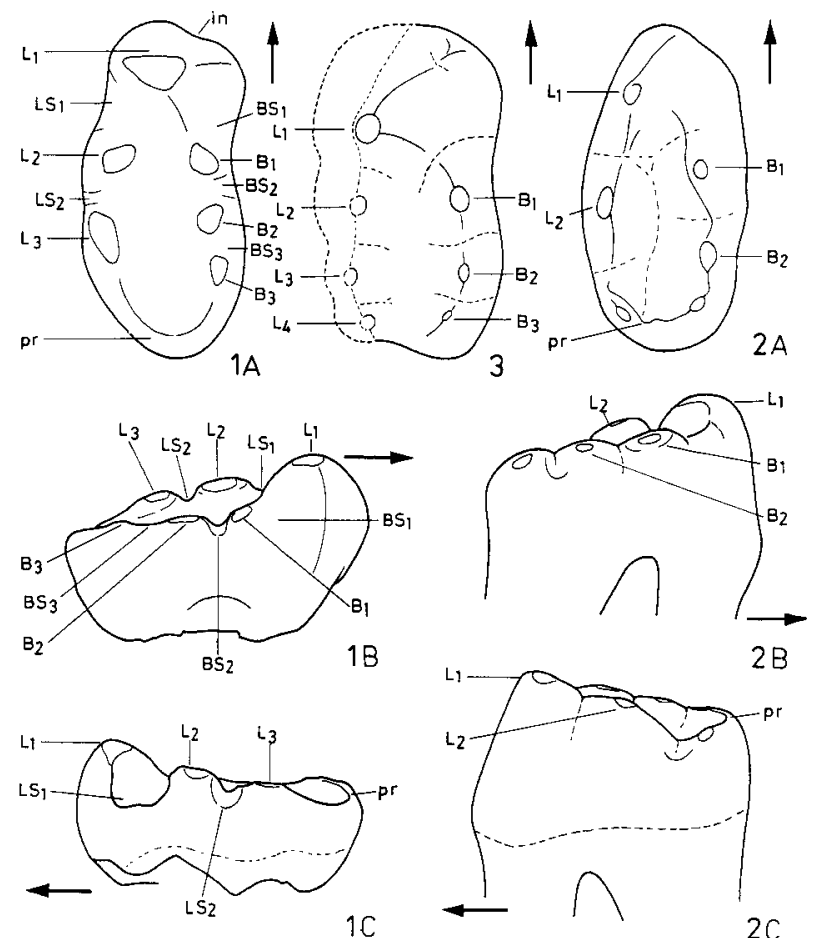

$2 \mathrm{~B}$
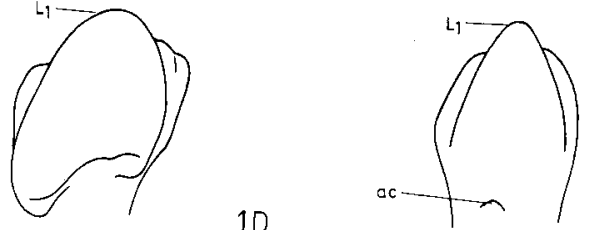

$2 C$

Fig. 2. Dental terminology of lower cheek teeth of haramiyid mammals used in the present account. 1 - Staffia aenigmatica gen. et sp. nov., presumed lower right posterior premolar, Upper Jurassic, Tendaguru, East Africa; 2 - Thomasia sp. (tooth group II sensu Sigogneau-Russell 1989), presumed lower posterior premolar, Upper Triassic, Saint-Nicolas-dePort, France; 3 - Haramiyavia clemmenseni, right lower $\mathrm{m} 1$, Upper Triassic, Greenland. The cheek teeth are shown in occlusal $(1 \mathrm{~A}, 2 \mathrm{~A}, 3)$, labial $(1 \mathrm{~B}, 2 \mathrm{~B})$, lingual $(1 \mathrm{C}, 2 \mathrm{C})$, and anterior view $(1 \mathrm{D}, 2 \mathrm{D}) . \mathrm{L}_{1}-\mathrm{L}_{4}-$ lingual cusps $1-3$; $\mathrm{LS}_{1}-\mathrm{LS}_{2}$ - lingual synclines $1-2 ; \mathbf{B}_{1}-\mathbf{B}_{3}$ - labial cusps $1-4 ; \mathrm{BS}_{1}-\mathrm{BS}_{3}$ - labial synclines $1-3 ;$ ac - anterobasal cingular cusp; in - indentation; pr - U-shaped posterior rim. Arrows point to front. Source: Figs 2A-2D: SigogneauRussell (1989), Fig. 3: Jenkins et al. (1997)
The mammals of the Middle Saurian Bed belong to a land vertebrate assemblage dominated by dinosaurs, notably Brachiosaurus brancai, Barosaurus africanus, Dicraeosaurus hansemanni, Kentrosaurus aethiopius, Dryosaurus lettow-vorbecki, Elaphrosaurus bambergi, Labrosaurus (?) stechowi, Ceratosaurus (?) roechlingi, and Allosaurus (?) tendagurensis (Janensch 1914b, 1925b, 1929, 1955, 1961; Hennig 1925). Pterosaurs (Janensch 1914b, Reck 1931, Unwin \& Heinrich 1999) and lizards (Broschinski 1999) have also been reported.

\section{Sediment processing}

The matrix from the Middle Saurian Bed that produced the mammal described in the present paper is a massive, greenish grey, partly sandy, partly clayey marl, containing mud clasts, reworked caliche nodules, oncoids, and irregularly dispersed dinosaur bones, mostly from Dryosaurus lettow-vorbecki (Heinrich 1999). The samples were first treated with $\mathrm{H}_{2} \mathrm{O}_{2}$ (about $5 \%$ by volume) to recover invertebrate microfossils (Schudack 1999, Schudack et al. 1999). In contrast to the mass accumulations of dinosaurs, microvertebrate remains do not occur in great concentrations. Therefore, the acid method was the only effective sampling technique to obtain mammalian remains from the Tendaguru Beds. Approximately 1 ton of matrix has been processed so far. All samples were treated with acetic or formic acid (about $5 \%$ by volume). The residues were washed out with water through an $0.5 \mathrm{~mm}$ mesh, dried, and hand sorted using a binocular microscope.

\section{Cusp terminology}

Haramiyid lower cheek teeth have two rows of longitudinally aligned cusps that decrease in height posteriorly and border a central basin. They are limited either by one cusp (premolars) or two cusps (molars) anteriorly and closed off by a cusped or rounded U-shaped rim posteriorly (e.g., Hahn 1973, Sigogneau-Russell 1989, Sigogneau-Russell \& Hahn 1994, Butler \& McIntyre 1994). Until the discovery of jaw fragments bearing teeth (Jenkins et al. 1997), the anatomical position and orientation of isolated haramiyid cheek teeth was uncertain (e.g., Simpson 1928a, Parrington 1947, Hahn 1973, Sigogneau-Russell 1989, Butler \& McIntyre 1994). Haramiyavia 
clemmenseni from the Upper Triassic of Greenland (Jenkins et al. 1997) shows that, as far as lower cheek teeth are concerned, the row with the highest mesial cusp (row A: Hahn 1973) is lingual (Jenkins et al. 1997), as previously suggested by Hahn (1973), Sigogneau-Russell (1989), and Butler \& McIntyre (1994). The cusps are numbered from the anterior to the posterior end of the tooth crown (e.g., Sigogneau-Russell 1989, Butler \& McIntyre 1994). The terminology for dental morphology of the lower haramiyid cheek teeth used in the description is summarized in Figure 2.

\section{Systematic Paleontology}

Class Mammalia Linnaeus, 1758

Subclass Allotheria Marsh, 1880

Order Haramiyida Hahn, 1973

Family Haramiyidae Simpson, 1947

\section{Staffia gen. nov.}

Etymology: In honour of the German geologist and paleontologist Hans von Staff (1883-1915) who ran excavations of the German Tendaguru expedition in 1911.

Ty pe species: Staffia aenigmatica gen. et sp. nov.

Diagnosis: The same as for the type species.

\section{Staffia aenigmatica gen. et sp. nov.}

Figs $3 \mathrm{~A}-3 \mathrm{E}, 4 \mathrm{~A}-4 \mathrm{~F}$

\section{Ety mology: From Latin, aenigma, enigma}

Holotype: MB.Ma. 48080; cheek tooth, tentatively identified as a right lower posterior premolar, housed in the collection of the Museum of Natural History of Humboldt University, Berlin, Institute of Paleontology.

Type locality: Tendaguru site Jg (Wj).

Stratigraphic data: Tendaguru Beds, Middle Saurian Bed, Upper Jurassic, KimmeridgianTithonian.

Associated local fauna: Brachiosaurus brancai, Elaphrosaurus bambergi, Dryosaurus lettow-vorbecki (Janensch 1925b, 1935, 1955), Kentrosaurus aethiopicus (Hennig 1925), Tendaguripterus recki (Unwin \& Heinrich 1999), a paramacellodid lizard (Broschinski 1999), Tendagurodon janenschi and Tendagurutherium dietrichi (Heinrich 1998).
Diagnosis: Based on a cheek tooth, tentatively identified as a lower posterior premolar. Tooth crown elongated, pinched in the anterior portion, tapered posteriorly, basined, with two longitudinally aligned rows of cusps decreasing successively in height and size posteriorly. Tworooted. Lingual and labial rows with three cusps bordering an elongated central basin limited by main cusp $\mathrm{L}_{1}$ anteriorly and closed off by an U-shaped rim posteriorly. Distinguished from previously described haramiyids by the presence of synclines (valleys) having well-rounded floors, in particular principal syncline $\mathrm{LS}_{1}$ that is situated between lingual cusps $\mathrm{L}_{1}$ and $\mathrm{L}_{2}$ and opened anterolingually. Syncline size decreases successively posteriorly. Principal cusp $\mathrm{L}_{1}$ placed more medially than the remaining cusps of the tooth crown. Anterior face of the tooth crown with an indentation, but without cingular ledge and basal cusps. Enamel surface smooth.

Description: The material consists of a fairly complete but heavily worn and corroded single cheek tooth, identified tentatively as a right lower posterior premolar, (Figs $3 \mathrm{~A}-3 \mathrm{E}, 4 \mathrm{~A}-4 \mathrm{~F}$ ). The tooth crown, as seen from above, is slender, pinched in the anterior portion, substantially longer than wide, broader mesially than distally, and slightly tapered towards the rounded posterior end. The anterior margin of the tooth crown is transverse, rounded, slightly indented, and recedes towards the labial margin. The latter is bilobate due to a constriction, located approximately on the middle of the labial half of the tooth crown. The lingual margin of the tooth crown is curved, but with two slight indentations corresponding to the external openings of synclines $\mathrm{LS}_{1}$ and $\mathrm{LS}_{2}$.

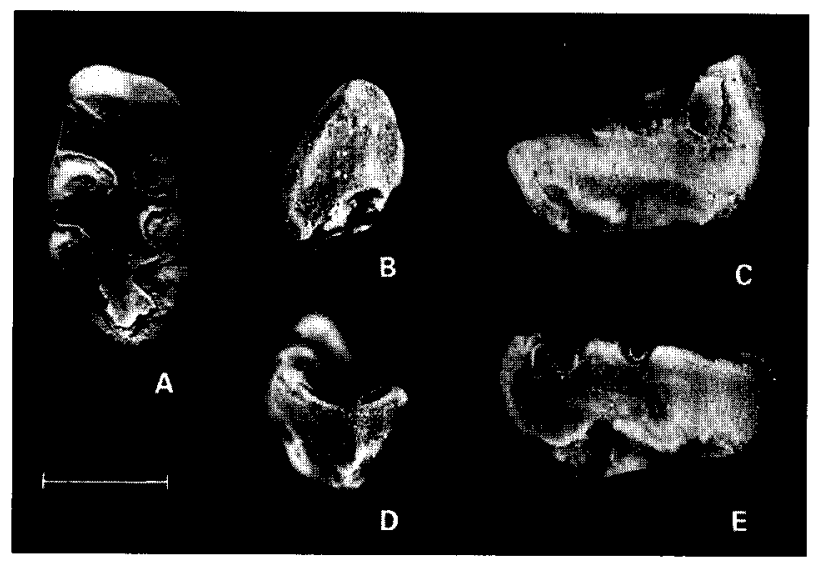

Fig. 3. Staffia aenigmatica gen. et sp. nov. from the Upper Jurassic of Tendaguru, Tanzania. Photographs of the type specimen, identified tentatively as a right lower posterior premolar in occlusal (A), anterior (B), labial $(\mathbf{C})$, posterior (D), and lingual views (E). Scale $=1 \mathrm{~mm}$ 


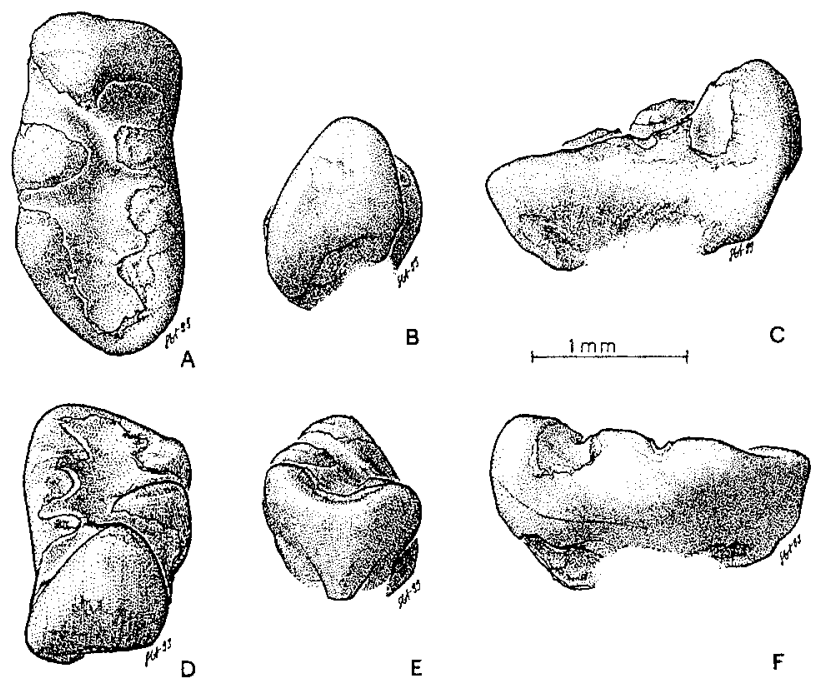

Fig. 4. Staffia aenigmatica gen. et sp. nov. from the Upper Jurassic of Tendaguru, Tanzania. Camera lucida drawings of the type specimen, identified tentatively as a right lower posterior premolar in occlusal (A), anterior (B), labial (C), anterodorsal $(\mathbf{D})$, posterior $(\mathbf{E})$, and lingual views $(\mathbf{F})$. Scale $=$ $1 \mathrm{~mm}$

The apices of all cusps lack their enamel (Figs 3A, 4A). Dentine is confluent between lingual cusp $\mathrm{L}_{3}$ and labial cusp $\mathrm{B}_{2}$, but the base of the cusps, and the floors of the central basin and synclines are still partly covered with enamel. The enamel surface is smooth, and there is no evidence of even a faint development of enamel ridges, either in the central basin or in the remaining enamel-covered portions of the tooth crown.

There are two rows of longitudinally aligned cusps bordering a large elongated central basin (Figs 3A, 4A). The labial row of cusps does not extend as far anteriorly as the lingual row. When viewed in transverse section, the cusps of the lingual row are higher and broader than those of the labial row.

The lingual row consists of three heavily worn cusps $\left(\mathrm{L}_{1}-\mathrm{L}_{3}\right)$, declining in size posteriorly, as do the cusps of the labial row. Cusps $\mathrm{L}_{1}$ and $\mathrm{L}_{2}$ appear to be conical with broad bases. Cusp $\mathrm{L}_{1}$ is displaced medial to cusp $\mathrm{L}_{2}$, and $\mathrm{L}_{3}$ somewhat lingual to $\mathrm{L}_{2}$. Therefore, the lingual cusp row axis is slightly arched and diverges from the longitudinal axis of the tooth crown (Figs 3A, $4 A, 4 D$ ). Cusp $L_{1}$ is anterior to cusp $B_{1}$, and the latter is opposite to $\mathrm{L}_{2}$. Cusp $\mathrm{L}_{3}$ is anterior to $\mathrm{B}_{3}$.

Principal cusp $L_{1}$, which is located close to the longitudinal midline of the tooth crown, is distinctly larger than the remaining cusps of both rows of cusps. Cusps $\mathrm{L}_{1}$ and $\mathrm{L}_{2}$ are separated by a broad and deep syncline $\left(\mathrm{LS}_{1}\right)$, open anterolin- gually with a broad mouth (Figs 3A, 3E, 4A, $4 \mathrm{~F})$. The transverse syncline $\mathrm{LS}_{2}$ that separates cusps $\mathrm{L}_{2}$ and $\mathrm{L}_{3}$ is also well developed, but shorter, distinctly smaller and narrower than syncline $\mathrm{LS}_{1}$. The bottom of syncline $\mathrm{LS}_{2}$ lies at a higher level than that of syncline $\mathrm{LS}_{1}$, when viewed in lingual aspect (Figs $3 \mathrm{E}, 4 \mathrm{~F}$ ). Cusp $\mathrm{L}_{3}$ is nearly worn away, indistinct in lingual aspect, and is continued posteriorly as a ridge-like rim that is strongly reduced by abrasion.

The labial row consists of at least three, distinct, aligned cusps $\left(\mathrm{B}_{1}-\mathrm{B}_{3}\right)$ that are heavily worn, with cusp $\mathrm{B}_{3}$ almost worn away. The cusps of the labial row do not show such a marked decrease in height posteriorly as those of the lingual row (Figs $3 \mathrm{C}, 3 \mathrm{E}, 4 \mathrm{C}, 4 \mathrm{~F}$ ). Cusp $\mathrm{B}_{1}$ is somewhat higher than $B_{2}$, but apparently they are the same length at the base. Cusp $B_{3}$ is smaller and lower than $B_{2}$, but lies in line with $B_{1}$ and $B_{2}$. The basic morphology, however, is barely discernible due to abrasion and corrosion. There is no evidence for further cusps posterior to cusp $B_{3}$. Cusps $B_{2}$ and $B_{3}$ are separated by a small, distinct, transverse groove (syncline $\mathrm{BS}_{2}$ ). At the back of the tooth crown, a heavily worn and rounded U-shaped rim links both cusp rows and closes off the central basin posteriorly (Figs 3D, $4 \mathrm{E})$.

Anterior to cusp $B_{1}$ there is a large transverse depression (syncline $\mathrm{LB}_{1}$ ) limited anteriorly by a bulge-like swelling positioned exactly in the region where a cusp of the labial row would be expected to occur. The swelling might be the result, either of the fusion of principal cusp $\mathrm{L}_{1}$ with a smaller neighbouring cusp, or of the reduction of an anterolabial cusp. Alternatively, the swelling might represent an incipient new labial cusp. Unfortunately, the enamel has broken away in the obscured area, and in view of this uncertainty, the structure is not identified as a cusp here. The precise assessment of this structure must await the discovery of more complete material.

The anterior portion of the central basin is relatively deep, narrow, and connected to the trough-like $\mathrm{LS}_{1}$ syncline anterolingually. It is broader between the medial slopes of cusps $\mathrm{L}_{3}$, and $B_{2}$, and shallow in the heavily worn posterior section (Figs $3 \mathrm{~A}, 4 \mathrm{~A}$ ). Cusp $\mathrm{B}_{2}$ and the principal cusp $L_{1}$ are linked by a low rounded ridge that separates the central basin anterolabially from the syncline $\mathrm{LB}_{1}$ (Figs $3 \mathrm{~A}, 4 \mathrm{~A}$ ).

There are no cingula or basal cusps at the base of the anterior face of the tooth crown (Figs 3B, 4B), but there is a well-developed in- 
dentation for reception of the posterior end of the preceding tooth.

The roots have been broken away. Judging from the cross-sections of the preserved bases, the anterior root was wider transversely than the posterior root. The latter was compressed linguolabially and extended longitudinally.

Measurements: The length of the tooth crown is $2.10 \mathrm{~mm}$; the maximum width is $1.10 \mathrm{~mm}$.

Comparison: Diagnostic characters of Staffia gen. nov. that indicate affinities with the Haramiyida are: (1) the different height of both rows of cusps bordering the central basin, (2) the progressive decline in cusp height posteriorly, and (3) the U-shaped posterior rim of the tooth crown.

Among the haramiyids, Staffia gen. nov. strongly resembles Thomasia from the Late Triassic and Early Jurassic of Europe (e.g., Plieninger 1847, Simpson 1928a, Parrington 1947, Peyer 1956, Hahn 1973, Clemens 1980, Sigogneau-Russel 1989, Sigogneau-Russell \& Hahn 1994; Butler \& McIntyre 1994). Characters that Staffia gen. nov. shares with presumed lower posterior premolars and anterior molars of Thomasia are: (1) two longitudinal rows of cusps; (2) cusp height that progessively decreases in both rows posteriorly; (3) a basined tooth crown; (4) the U-shaped posterior rim of the tooth crown; and (5) a smooth enamel surface. A character that distinguishes Staffia gen. nov. from Thomasia is the presence of well-developed rounded synclines, most notably the trough-like syncline $\mathrm{LS}_{1}$.

Presumed posterior premolars of Thomasia (tooth group II, Sigogneau-Russell 1989: 152 to 156, figs 17-21) share with Staffia gen. nov. the (1) a more medial position of principal cusp $L_{1}$ that closes the central basin anteriorly, (2) the position of the lingual row of cusps, which extends more anteriorly than the labial row, and (3) a single-peaked anterior profile (e.g., Sigogneau-Russell 1989: 151-156, figs 18-21, pl.2, fig. d), but differs markedly in the absence of well-developed synclines such as syncline $\mathrm{LS}_{1}$, as previously mentioned. Further differences concern the cusp arrangement in the anterior portion of the tooth crown. In presumed Thomasia premolars (tooth group II sensu Sigogneau-Russell 1989), labial cusp B1 corresponds to the notch between cusps $L_{1}$ and L2 (Fig. 2 ). By contrast, cusp B1 in Staffia gen. nov. lies opposite to cusp L2 (Fig. 2).
The dimensions of the Tendaguru tooth (length: $2.1 \mathrm{~mm}$; width: $1.0 \mathrm{~mm}$ ) falls within the known size range for Thomasia (tooth groop II sensu Sigogneau-Russel 1989), which is from 1.36 and $2.17 \mathrm{~mm}$ in length and 0.84 and $1.17 \mathrm{~mm}$ in width (Sigogneau-Russell 1989: 152).

Presumed anterior molars of Thomasia (tooth group I sensu Sigogneau-Russell 1989, Sigogneau-Russell \& Hahn 1994) differ from Staffia gen. nov. in having: (1) a transverse saddle-like ridge linking the cusps $\mathrm{L}_{1}$ and $\mathrm{B}_{1}$; (2) a distinct anterior basin; and (3) a double-peaked anterior profile (e.g., T. moorei: Parrington 1947: 718, fig. 7; Butler \& McIntyre 1994: 445, fig. 8; T. antiqua: Butler \& McIntyre 1994: 449; T. hahni: Hahn 1973: 6, fig. 2, described as T. sp. 1; Butler \& McIntyre 1994: 450; Haramiyidae XLI: Peyer 1956: 12, plate 1, figs 41a-d; Butler \& McIntyre 1994: 447, 449; Thomasia, tooth group I, Sigogneau-Russell 1989: 140-151, figs 3-15, plate 1 , fig. d).

The cusp arrangement and the bilobate labial margin of the tooth crown of Staffia gen. nov. is somewhat reminiscent of the crown pattern of the first lower molar in Haramiyavia clemmenseni from the Upper Triassic of Greenland (Jenkins et al. 1997: 716, fig. 1e). However, the latter differs markedly from Staffia gen. nov. in having four lingual and labial cusps, and a tooth crown with a roughly rectangular shape. The posterior end of the tooth crown is tapered in Staffia gen. nov., but rounded and indented in $\mathrm{M}_{1}$ of Haramiyavia (Fig. 2). Moreover, in Staffia gen. nov. the floor of the central basin is deeper anteriorly than posteriorly, while the reversel is true for the $\mathrm{M}_{1}$ of Haramiyavia (Jenkins et al. 1997). Occlusal views of lower premolars of Haramiyavia have not yet been published. The labial view of the premolars of Haramiyavia (Jenkins et al. 1997: 716, fig. 1c) suggests that their proportions are different from those of Staffia gen. nov.

The comparison shows that Staffia gen. nov. resembles Thomasia more than Haramiyavia. Moreover, the tooth crown pattern of Staffia gen. nov. is closer to presumed posterior lower premolars of Thomasia (tooth group II: Sigogneau-Russell 1889) than to anterior lower molars of Thomasia (tooth group I: Sigogneau-Russell 1989). Thus, the Tendaguru specimen is identified tentatively here as a posterior lower premolar.

A heavily worn tooth from the Middle Jurassic (Bathonian) of England shows some resemblance to haramiyid and multituberculate cheek 
teeth (Freeman 1976: 232, plate 1, 1979; Butler \& McIntyre 1994), but has a subrectangular tooth crown supported by three roots, a condition that is markedly different from that of the presumed lower posterior premolar from the Tendaguru Beds (Fig. 3A, 4A).

The relationships of the Tendaguru specimen to a presumed haramiyid molariform tooth from the Lower Jurassic Kayenta Formation (Jenkins et al. 1983: 1233, fig. 1c) are difficult to determine. The latter apparently shows features of upper molariform teeth of haramiyids including a rounded subrectangular tooth crown, and a central basin that is closed off anteriorly by a rounded rim. Staffia gen. nov. from Tendaguru lacks all these characters.

Staffia aenigmatica gen. et sp. nov. shares the following character, 'two longitudinally cusped tooth rows', with the Haramiyida and with the Multituberculata (e.g. Hahn 1969, Clemens \& Kielan-Jaworowska 1979, Hahn \& Hahn 1998a, b). The latter were unknown in Africa prior to the discovery of Hahnodon taqueti in the Early Cretaceous (Berriasian ?) of the Anoual Syncline, Oriental High Atlas, Morocco, by Sigogneau-Russell (1991). This species, which has been assigned tentatively to the Plagiaulacoidea, is based on a last lower molar that has a rounded, quadratic shape (Sigogneau-Russell 1991: 120, figs 1 and 2) which differs distinctly from the Tendaguru specimen. Posterior premolars of Hahnodon are so far unkown.

The Late Jurassic to Early Cretaceous representatives of the Paulchoffatiidae (e.g., Paulchoffatia, Kuehneodon) from Europe share with the presumed posterior lower premolar from Tendaguru the presence of two rows of anteroposteriorly aligned cusps, but differ markedly in the crown pattern of $\mathrm{P}_{4}$ (lingual row high, blade-like, tipped with a series of cusps; labial row reduced to vestigal basal cusps). The rounded quadratic shape of the anterior lower molars of paulchoffatiid multituberculates (e.g., Kuehneodon, Meketibolodon: Hahn \& Hahn 1998a: 16, fig. 4; Hahn \& Hahn 1998b: 67, figs 34a, b; Guimarotodon: Hahn \& Hahn 1998a: 28, figs 24-28; Hahn \& Hahn 1998b: 67, fig. 34c; Bolodon, Kielan-Jaworowska \& Ensom 1992: 11, plate 3, fig. 3) also contrasts with the condition in Staffia gen. nov.

Comparing the Tendaguru specimen with Late Jurassic multituberculates, the tooth crown morphology of Staffia gen. nov. appears superficially similar to that of the posterior upper premolars $\left(\mathrm{P}^{5}\right)$ and anterior upper molars $\left(\mathrm{M}^{1}\right)$ of the paulchoffatiid Kuehneodon (see Hahn 1969: 75, figs $67-68 ; 78$, fig. $75 ; 1973$ : 12 , figs $8-10$; Hahn \& Hahn 1998b: 44, fig. 1b). However, several features of the latter (e.g., small height differences between the cusps, a central basin that is open posterolabially, and distinct enamel ridges) show that the Tendaguru specimen is not comparable with posterior upper premolars or anterior upper molars of Kuehneodon.

The lower cheek teeth of the Theroteinidae from the Lower Rhaetian of France (e.g., Theroteinus nikolai: Hahn et al. 1989: 206, figs 1-3; Theroteinus sp.: Hahn et al. 1989: 210, figs 9-11) share with the Tendaguru specimen the arrangement of the cups in two longitudinal rows bordering a central basin, but differ from the presumed lower premolar of Staffia gen. nov. in having very low rounded cusps. According to Hahn et al. (1989) the presumed haramiyid tooth from the Kayenta-Formation of Arizona could be related to the theroteinid Theroteinus (Sigogneau-Russell et al. 1986) or Mojo (Hahn et al. 1987, 1989). The latter is a poorly known allotherian taxon from the Upper Triassic of Belgium and is considered as an early paulchoffatiid multituberculate (Hahn et al. 1989).

Presumed multituberculate-like lower molars of the Eleutherodontida from the Middle Jurassic Forest Marble of Kirtlington (Oxfordshire), England (Eleutherodon oxfordensis: Kermack et al. 1998: 593-597, figs 15-21) differ markedly from the Tendaguru specimen in having a labial row of cusps that is higher than the lingual row, lingual and labial margins with a varying number of up to 21 cusps, and a central basin open anteriorly. Close relationships between eleutherodontid allotherians, and Staffia gen. nov. appear unlikely.

The fossil material of Staffia aenigmatica gen. et sp. nov. appears, at first glance, somewhat limited, as the new taxon is only known so far from a single badly preserved lower cheek tooth. However, Staffia gen. nov. has a tooth crown morphology different from that of known haramiyids that the introduction of a new genus and species is justified. The key difference between Staffia gen. nov. and the previously described haramiyids is the presence of synclines such as the trough-like $\mathrm{LS}_{1}$ syncline.

\section{Occlusion and chewing}

Conclusions concerning patterns of occlusion and chewing in Staffia gen. nov. are strongly hampered by the incomplete state of preservation. 
Owing to extensive loss of enamel, available information on the mode of wear is sparse, and the extent to which enamel was lost during life cannot be assessed with certainty. Distinct breaks and gaps in the enamel cover of the central basin indicate that some loss of enamel must have been post mortem, possibly due to damage by acid during processing of the sediments (Figs 3A, 3C).

The labial row of cusps is more heavily worn than the lingual row (Figs 3A, 4A). Cusps $\mathrm{L}_{1}$ and $\mathrm{L}_{2}$, rounded by wear, have almost completely lost their enamel, but show triangular $\left(\mathrm{L}_{1}\right)$ and rounded facets on their tips $\left(\mathrm{L}_{2}\right)$. A distinct wear pit is also seen on cusp $B_{1}$ suggesting that the enamel on the tip was breached during life (Figs 3A, 4A). Cusps $\mathrm{L}_{3}$ and $\mathrm{B}_{3}$ are reduced by wear to barely discernible elevations (Figs 3C, $3 \mathrm{E}, 4 \mathrm{C}, 4 \mathrm{~F})$.

Fine wear striations have not been found under the binocular microscope. This is regrettable, because the direction of wear striations reflect the the direction of jaw movements during the chewing cycle (e.g., Krause 1982, Sigogneau-Russell 1989; Butler \& McIntyre 1994, Kermack et al. 1998). Their absence may be due to corrosion or possibly to specializations in soft diet, as has been suggested for the Paleocene multituberculate Ptilodus (Krause 1982).

In the Late Triassic to Early Jurassic haramiyid Thomasia, the masticatory movement "was restricted to a longitudinal direction" (Butler \& McIntyre 1994: 451) because of the specific arrangement of the tooth cusps in two rows. Premolars and molars "functioned in a propalinal chewing action in which the effective power stroke was probably in a backward direction" (Butler \& McIntyre 1994: 451). During the chewing cycle, the plant food "could be cut between the the serrated edges" of the lingual and labial rows "and further reduced by a pounding-grinding action in the basin by the B1 cusp" (Butler \& McIntyre 1994: 451).

The worn state of the Tendaguru specimen makes it difficult to draw conclusions regarding occlusion and chewing. However, retention of the basic tooth crown pattern of haramiyids in the Tendaguru tooth (e.g., two longitudinal rows of cusps bordering a central basin, the different height of both rows, a cusp height that progressively decreases posteriorly, and a U-shaped posterior rim) suggests that occlusion and chewing in Staffia gen. nov. might have been similar in many respects to that of Late Triassic to Early Jurassic haramiyids such as Thomasia. The key difference between these taxa concerns the presence of well-developed synclines in Staffia gen. nov. This dental feature suggests that food items, that had been previously pounded and concentrated in the central basin were pressed through the synclines, mainly through the principal syncline $\mathrm{LS}_{1}$, and then were swallowed.

Further discussions are deferred here, since an upper molar, which was recovered from the matrix after the completion and submission of the manuscript, will probably provide more details about the occlusion and chewing of the Tendaguru haramiyid.

\section{Conclusions}

The basic tooth crown pattern and the dimensions of Staffia gen. nov. strikingly resembles Thomasia (tooth group II sensu Sigogneau-Russell 1989) in many aspects. Therefore, the Tendaguru specimen is tentatively identified as a posterior lower premolar. Moreover, it is argued here that the tooth crown pattern of Staffia gen. nov. might have developed from a primitive condition similar to that of the Late Triassic to Early Jurassic Thomasia. The major difference between Thomasia (tooth group II sensu Sigogneau-Russell 1989) and Staffia gen. nov. concerns the presence of deep synclines with rounded floors, especially that of the principal syncline $\mathrm{LS}_{1}$. This dental character suggests that pounded foodstuff was transported through the synclines to the digestive tract.

The tooth crown morphology of the Tendaguru specimen strongly resembles Thomasia, therefore, Staffia aenigmatica gen. et sp. nov. is referred to the Haramiyida. This assignment implies a considerable biochronological and palaeobiogeographical range extension for haramiyids. All hitherto uncontested records of haramiyids are from Upper Triassic to Lower Jurassic deposits of the Northern Hemisphere (e.g. Parrington 1947, Hahn 1973, Hahn \& Hahn 1983, Sigogneau-Russell 1989, Butler \& McIntyre 1994, Jenkins et al. 1983, 1997). Staffia aenigmatica gen. et sp. nov. extends the stratigraphic range of haramiyids to the Late Jurassic, and is the first record of a haramiyid from Gondwana.

Staffia aenigmatica gen. et sp. nov. represents an allotherian mammal group that was previously unknown from the Mesozoic of Africa. It reveals also that haramiyids were more widely dispersed than previously thought. However, nothing can be said about dispersal events and 


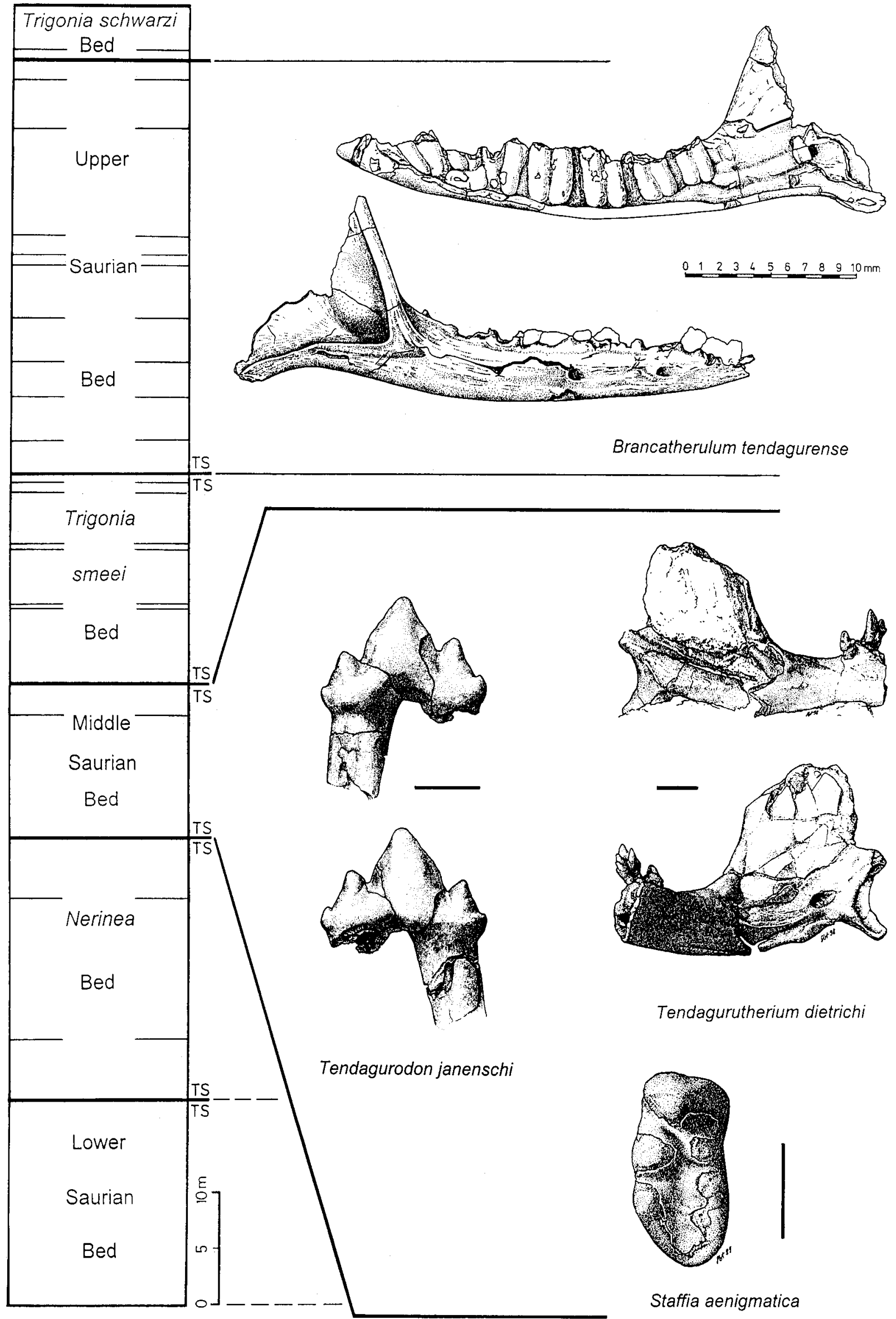

Fig. 5. Diagram showing the stratigraphic distribution of the mammalian remains in the Tendaguru Beds. TS - Transitional Sands. Source: Heinrich (1991, 1998, unpublished). Figures of Tendagurodon janenschi and Tendagurutherium dietrichi (medial view) reproduced from Journal of Mammalian Evolution, 5 (4), p. 273, figs 2B, 2C and p. 276, fig. 4C 
the interchange of these allotherian mammals between Laurasia and Africa due to the lack of an adequate fossil record.

Staffia aenigmatica gen. et sp. nov. belongs to a mammalian assemblage of the Upper Jurassic Tendaguru Beds that is still poorly known (Fig. 5). Only a haramiyid (Staffia aenigmatica gen. et sp. nov.), a triconodont (Tendagurodon janenschi) and two 'eupantotherian' mammals (Brancatherulum tendagurense, Tendagurutherium dietrichi) have been described so far (Dietrich 1927, Simpson 1928b, Heinrich 1998, 1999). Even though the Tendaguru mammal assemblage is still incompletely known, it nevertheless sheds some light on the evolution and the distribution of Late Jurassic mammals in Africa for the first time. Some representatives of this poorly known mammal assemblage from Tendaguru retained primitive characters of their Late Triassic to Early Jurassic ancestors. These include Staffia aenigmatica gen. et sp. nov., Tendagurodon janenschi, and, most importantly, Tendagurutherium dietrichi, which still possessed a mandibular eardrum (Heinrich 1998). The available evidence from Tendaguru, therefore, might suggest the existence of an East African faunal province where mammals with primititve characters apparently survived longer than in other regions of the southern and northern hemisphere.

\section{Acknowledgements}

I am grateful to Prof. Dr. B. Krebs (Freie Universität Berlin), Dr. T. Martin (Freie Universität Berlin), Dr. T. Rich (Museum of Victoria, Melbourne), and Dr. Sigogneau-Russell (Musém National d'Histoire Naturelle, Paris), for critical comments. My sincere thanks are extended Dr. D. Unwin (Humboldt-Universität zu Berlin) for suggestions and improvements to the English, to Dr. M. Aberhan (Humboldt-Universität zu Berlin), Prof. Dr. H. Keupp and Dr. M. Schudack (Freie Universität Berlin) for comments on the lithology of the matrix from Tendaguru Beds, to Mrs. E. Mosmann, Mrs. A. Tausch, and Mr. A. Manegold (Freie Unversität Berlin) for their help in processing the sediments and sorting out the residues, to Mrs. E. Siebert (Humboldt-Universität Berlin) for the camera lucida drawings, and Mrs. V. Heinrich (Humboldt-Universität $\mathrm{zu}$ Berlin) for drawings and photographs. Financial support from the Deutsche Forschungsgemeinschaft (He 2757/1-1) is gratefully acknowledged.

\section{References}

Aitken, W. G. 1956. The Jurassic-Cretaceous junction in Tanganyika. - East-Central Regional Committee for Geology, Commission for Technical Cooperation in Africa south of the Sahara 1956: 67-71.

- 1961. Geology and Palaeontology of the Jurassic and Cretaceous of Southern Tanganyika. - Bulletin of the Geological Survey of Tanganyika 31: 1-144.
Branca, W. 1915. Einige Betrachtungen über die ältesten Säuger der Trias- und Liaszeit. - Abhandlungen der Königlich Preußischen Akademie der Wissenschaften, Physikalisch-Mathematische Klasse 1915 (5): 1-77.

- 1916. Ein Säugetier? - Unterkiefer aus den TendaguruSchichten. - Archiv für Biontologie 4 (1): 137-140.

Broschinski, A. 1999. Ein Lacertilier (Scincomorpha, Paramacellodidae) aus dem Oberen Jura von Tendaguru/Tansania. - Mitteilungen aus dem Museum für Naturkunde Berlin, Geowissenschaftliche Reihe 2: 155-158.

Butler, P. M. \& MacIntyre, G. T. 1994. Review of the British Haramiyidae (? Mammalia, Allotheria), their molar occlusion and relationships. - Philosophical Transactions of the Royal Society of London 345: 433-458.

Clemens, W. A. 1980. Rhaeto-Liassic mammals from Switzerland and West-Germany. - Zitteliana 5: 51-92.

- 1988. On Triassic and Jurassic mammals. In Padian, K. (ed.). The Beginning of the Age of Dinosaurs. Faunal Change across the Triassic-Jurassic Boundary. 237-246, Cambridge University Press, New York, New Rochelle, Melbourne, Sydney.

Clemens, W. A. \& Kielan-Jaworowska, Z. 1979. Multituberculata. In Lillegraven, J. A., Kielan-Jaworowska, Z. \& Clemens, W. A. (eds.). Mesozoic mammals. The first twothirds of mammalian history. 99-149, University of California Press, Berkely.

Dawkins, W. B. 1864. On the Rhaetic Beds and White Lias of Western and Central Somerset, and on the discovery of a new fossil mammal in the Grey Marlstones beneath the bone-bed. - Quarterly Journal of the Geological Society of London 20: 396-412.

Dietrich, W. O. 1927. Brancatherulum n. g., ein Proplacentalier aus dem obersten Jura des Tendaguru in Deutsch-Ostafrika. - Centralblatt für Mineralogie, Geologie, Paläontologie, Abt. B, 1927 (10): 423-426.

- 1933. Zur Stratigraphie und Palaeontologie der Tendaguruschichten. - Palaeontographica, Supplement VII, 2. Reihe, Teil II, Lieferung 1: 1-86.

Fraas, E. 1908. Ostafrikanische Dinosaurier. - Palaeontographica 55: 105-144.

Freeman, E. F. 1976. A mammalian fossil from the Forest Marble (Middle Jurassic) of Dorset. - Proc. Geol. Ass. 87 (2): $231-235$

- 1979. A Middle Jurassic mammal bed from Oxfordshire. - Palaeontology 22 (1): 135-166.

Hahn, G. 1969. Beiträge zur Fauna der Grube Guimarota. Nr. 3. Die Multituberculata. - Palaeontographica, A, 133: $1-100$.

- 1973. Neue Zähne von Haramiyiden aus der deutschen Ober-Trias und ihre Beziehungen zu den Multituberculaten. - Palaeontographica, A, 142: 1-15.

Hahn, G. \& Hahn, R. 1983. Multituberculata. - Fossilium Catalogue I: Animalia, pars 127, 409 pp., Kugler Publications, Amsterdam.

- 1998a. Neue Beobachtungen an Plagiaulacoidea (Multituberculata) des Ober-Juras. 2. Zum Bau des Unterkiefers und des Gebisses bei Meketibolodon und bei Guimarotodon. - Berliner Geowiss. Abh. E28: 9-37.

- 1998b. Neue Beobachtungen an Plagiaulacoidea (Multituberculata) des Ober-Juras. 3. Der Bau der Molaren bei den Paulchoffatiidae. - Berliner Geowiss. Abh. E28: 39-89.

Hahn, G., Lepage, J. C. \& Wouters, G. 1987. Ein Multituberculaten-Zahn aus der Ober-Trias von Gaume (S-Belgien). - Bulletin de la Société Belge de Géologie 96 (1): 39-47.

Hahn, G., Sigogneau-Russell, D. \& Wouters, G. 1989. New data on Theroteinidae - their relations with Paulchoffatiidae and Haramiyidae. - Geologica et Palaeontologica 23: $205-215$.

Heinrich, W.-D. 1991. Über Brancatherulum tendagurense Dietrich, 1927 (Mammalia: Eupantotheria) aus dem Oberjura von Tendaguru, Tansania. Vorläufige Mitteilung. - Mitteilungen aus dem Zoologischen Museum Berlin 67 (1): 97-104. 
- 1998. Late Jurassic mammals from Tendaguru, Tanzania, East Africa. - Journal of Mammalian Evolution 5 (4): $269-290$

- 1999. The taphonomy of dinosaurs from the Upper Jurassic of Tendaguru, Tanzania (East Africa), based on field sketches of the German Tendaguru expedition (1909-1913). - Mitteilungen aus dem Museum für Naturkunde Berlin, Geowissenschaftliche Reihe 2: 25-61.

Hennig, E. 1914. Beiträge zur Geologie und Stratigraphie Deutsch-Ostafrikas. - I. Geologisch-stratigraphische Beobachtungen im Küstengebiete des südlichen DeutschOstafrika. II. Geologisch-stratigraphische Beobachtungen im Gebiet der Jura-Ablagerungen an der Deutsch-ostafrikanischen Zentralbahn. - Archiv für Biontologie 3 (3): $1-72$.

- 1925. Kentrurosaurus aethiopicus: die Stegosaurierfunde vom Tendaguru, Deutsch-Ostafrika. - Palaeontographica, Supplement VII, 1 Reihe, Teil 1, Lieferung 2: 100-253.

Janensch, W. 1914a. Bericht über den Verlauf der Tendaguru-Expedition. - Archiv für Biontologie 3 (1): 17-58.

- 1914b. Übersicht über die Wirbeltierfauna der Tendaguru-Schichten, nebst einer kurzen Charakterisierung der neu aufgestellten Arten von Sauropoden. - Archiv für Biontologie 3 (1): 81-110.

- 1914c. Die Gliederung der Tendaguru-Schichten im Tendaguru-Gebiet und die Entstehung der Saurier-Lagerstätten. - Archiv für Biontologie 3 (3): 227-261.

- 1925a. Die Grabungsstellen der Tendaguru-Gegend. Palaeontographica, Supplement VII, 1 Reihe, Teil 1, Lieferung 1: XVII-XIX.

- 1925b. Die Coelurosaurier und Theropoden der Tendaguru-Schichten Deutsch-Ostafrikas. - Palaeontographica, Supplement VII, 1 Reihe, Teil 1, Lieferung 1: 1-97.

- 1929. Material und Formengehalt der Sauropoden in der Ausbeute der Tendaguru-Expedition. - Palaeontographica, Supplement VII, 1 Reihe, Teil 2, Lieferung 1: $1-34$.

- 1935. Die Schädel der Sauropoden Brachiosaurus, Barosaurus und Dicraeosaurus aus den Tendaguru-Schichten Deutsch-Ostafrikas.- Palaeontographica, Supplement VII, 1 Reihe, Teil 2, Lieferung 1: 145-248.

- 1955. Der Ornithopode Dysalotosaurus der Tendaguruschichten. - Palaeontographica, Supplement VII, 1 Reihe, Teil 3, Lieferung 3: 105-176.

- 1961. Die Gliedmaßen und Gliedmaßengürtel der Sauropoden der Tendaguru-Schichten. - Palaeontographica, Supplement VII, 1. Reihe, Teil III, Lieferung 4: 177-235.

Jenkins, F. A. Jr., Crompton, A. W. \& Downs, W. R. 1983. Mesozoic Mammals from Arizona: New Evidence on Mammalian Evolution. - Science 222: 1233-1235.

Jenkins, F. Jr., Gatesy, S. M., Shubin, N. H. \& Amaral, W. W. 1997. Haramiyids and Triassic mammalian evolution. Nature 385: $7.15-718$.

Kermack, K. A., Kermack, D., Lees, P. M. \& Mills, J. R. E. 1998. New multituberculate-like teeth from the Middle Jurassic of England. - Acta Palaeontologica Polonica 43 (4): 581-606.

Kielan-Jaworowska, Z. 1992. Interrelationships of Mesozoic Mammals. - Historical Biology 6: 185-202.

Kielan-Jaworowska, Z. \& Ensom, P. C. 1992. Multituberculate mammals from the Upper Jurassic Purbeck Limestone Formation of Southern England. - Palaeontology 35 (1): $95-126$.

Krause, D. W. 1982. Jaw movement, dental function, and diet in the Paleocene multituberculate Ptilodus. - Paleobiology 8 (3): 265-281.

Maier, G. 1997. Tendaguru. In Curry P. J. \& Padian, K. (eds.). Ecyclopedia of Dinosaurs. 725-726, Academic Press, San Diego.

McKenna, M. C. \& Bell, S. K. 1997. Classification of Mammals above the Species Level. 632 pp., Columbia University Press, New York.
Miao, D. 1991. On the origins of mammals. In Schultze, H.-P. \& Trueb, L. (eds.). Origins of the Higher Groups of Tetrapods. Controversy and Consensus. 579-597, Comstock Publishing Associates, Ithaca, London.

Parkinson, J. 1930. The Dinosaur in East Africa. 188 pp., H. F. \& G. Witherby, London.

Parrington, F. R. 1947. On a collection of Rhaetic mammalian teeth. - Proceedings of the Zoological Society of London 116 (3/4): 707-728.

Peyer, B. 1956. Über Zähne von Haramiyiden, von Triconodonten und von wahrscheinlich synapsiden Reptilien aus dem Rhät von Hallau, Kt. Schaffhausen, Schweiz. Schweizerische Paläontologische Abhhandlungen $\mathbf{7 2}$ : $1-72$.

Plieninger, W. H. von 1847. Abbildungen von Zähnen aus der oberen Grenzbreccie des Keupers bei Degerloch und Steinenbronn. - Jahreshefte des Vereins für vaterländische Naturkunde in Württemberg 2: 164-167.

Reck, H. 1931. Die deutschostafrikanischen Flugsaurier. Centralblatt für Mineralogie, Geologie und Paläontologie Abt. B, 1931: 321-336.

Russell, D., Béland, P. \& McIntosh, J. S. 1980. Paleoecology of the dinosaurs of Tendaguru (Tanzania). - Mémoirs de la Société Geologique de France, N. S. 139: 169-175.

Schrank, E. 1999. Palynology of the dinosaur beds of Tendaguru (Tanzania) - preliminary results. - Mitteilungen aus dem Museum für Naturkunde Berlin, Geowissenschaftliche Reihe 2: 171-183.

Schudack, M. 1999. Charophytes from the Middle Dinosaur Member of the Tendaguru Formation (Upper Jurassic of Tanzania). - Mitteilungen aus dem Museum für Naturkunde Berlin, Geowissenschaftliche Reihe 2: 201-205.

Schudack, M. E., Schudack, U. \& Pietrzeniuk, E. 1999. Ostracods from the Middle Dinosaur Member of the Tendaguru Formation (Upper Jurassic of Tanzania). - (manuscript)

Sigogneau-Russell, D. 1989. Haramiyidae (Mammalia, Allotheria) en provenance du Trias superieur de Lorraine (France). - Palaeontographica, Abt. A, 206: 137-198.

- 1991. First evidence of Multituberculata (Mammalia) in the Mesozoic of Africa. - Neues Jahrbuch für Geologie und Paläontologie, Mh., 1991 (2): 119-125.

Sigogneau-Russell, D., Frank, R. M. \& Hemmerlé, J. 1986. A new family of mammals from the lower part of the French Rhaetic. In Padian, K. (ed.). The beginning of the age of dinosaurs. Faunal change across the Triassic-Juratssic boundary. 99-108, Cambridge University Press, Cambridge.

Sigogneau-Russell, D. \& Hahn, G. 1994. Late Triassic microvertebrates from central Europe. In Fraser, N. \& Sues, H.-D. (eds.). In the Shadow of the Dinosaurs. Early Mesozoic Tetrapods. 197-213, Cambridge University Press, Cambridge.

Simmons, N. B. 1993. Phylogeny of Multituberculata. In Szalay, F. S., Novacek, M. J. \& McKenna, M.C. (eds.). Mammal Phylogeny. Mesozoic Differentiation, Multituberculates, Monotremes, Early Therians, and Marsupials. 146-164, Springer-Verlag, Berlin, New York, Heidelberg.

Simpson, G. G. 1928a. A Catalogue of the Mesozoic Mammalia in the British Museum. 215 pp., The British Museum (Natural History), London.

1928b. Mesozoic Mammalia. XI. Brancatherulum tendagurense DIETRICH. - American Journal of Science 15: 303-308.

Spath, L. F. 1927-1933. Revision of the Jurassic cephalopod fauna of Kachh (Cutch). - Memoirs of the Geological Survey of India, Palaeontologica Indica, new ser., vol. 9, mem. 2, pt. 1-6: 1-945.

Unwin, D. \& Heinrich, W.-D. 1999. On a pterosaur jaw remain from the Upper Jurassic of Tendaguru, East Africa. - Mitteilungen aus dem Museum für Naturkunde Berlin, Geowissenschaftliche Reihe 2: 121-134. 